\title{
Analysis of Phosphorus Use Efficiency Traits in Coffea Genotypes Reveals Coffea arabica and Coffea canephora Have Contrasting Phosphorus Uptake and Utilization Efficiencies
}

\author{
Ana P. Neto ${ }^{1 *}$, José L. Favarin ${ }^{1}$, John P. Hammond ${ }^{2}$, Tiago Tezotto ${ }^{3}$ and Hilton T. Z. Couto ${ }^{4}$ \\ 1 Departamento de Produção Vegetal, Escola Superior de Agricultura Luiz de Queiroz, Universidade De São Paulo, \\ Piracicaba, Brazil, ${ }^{2}$ School of Agriculture, Policy and Development and Centre for Food Security, Reading, UK, ${ }^{3}$ Centro \\ Universitário da Fundação Octavio Bastos, São João da Boa Vista, Brazil, ${ }^{4}$ Departamento de Recursos Florestais, Escola \\ Superior de Agricultura Luiz de Queiroz, Universidade De São Paulo, Piracicaba, Brazil
}

\section{OPEN ACCESS}

Edited by:

Richard William Bell,

Murdoch University, Australia

Reviewed by:

Monika Wimmer,

University of Bonn, Germany

Bernard Dell,

Murdoch University, Australia

*Correspondence:

Ana P. Neto

apneto@usp.br

Specialty section: This article was submitted to

Plant Nutrition,

a section of the journal

Frontiers in Plant Science

Received: 21 October 2015

Accepted: 17 March 2016

Published: 31 March 2016

Citation:

Neto AP, Favarin JL, Hammond JP,

Tezotto T and Couto HTZ (2016)

Analysis of Phosphorus Use Efficiency

Traits in Coffea Genotypes Reveals

Coffea arabica and Coffea canephora

Have Contrasting Phosphorus Uptake and Utilization Efficiencies.

Front. Plant Sci. 7:408

do: 10.3389/fpls.2016.00408
Background and Aims: Phosphate $(\mathrm{Pi})$ is one of the most limiting nutrients for agricultural production in Brazilian soils due to low soil Pi concentrations and rapid fixation of fertilizer Pi by adsorption to oxidic minerals and/or precipitation by iron and aluminum ions. The objectives of this study were to quantify phosphorus (P) uptake and use efficiency in cultivars of the species Coffea arabica L. and Coffea canephora L., and group them in terms of efficiency and response to Pi availability.

Methods: Plants of 21 cultivars of C. arabica and four cultivars of C. canephora were grown under contrasting soil $\mathrm{Pi}$ availabilities. Biomass accumulation, tissue $\mathrm{P}$ concentration and accumulation and efficiency indices for $\mathrm{P}$ use were measured.

Key Results: Coffee plant growth was significantly reduced under low Pi availability, and $P$ concentration was higher in cultivars of $C$. canephora. The young leaves accumulated more $P$ than any other tissue. The cultivars of $C$. canephora had a higher root/shoot ratio and were significantly more efficient in $\mathrm{P}$ uptake, while the cultivars of $C$. arabica were more efficient in $\mathrm{P}$ utilization. Agronomic $\mathrm{P}$ use efficiency varied among coffee cultivars and E16 Shoa, E22 Sidamo, lêmen and Acaiá cultivars were classified as the most efficient and responsive to Pi supply. A positive correlation between P uptake efficiency and root to shoot ratio was observed across all cultivars at low Pi supply. These data identify Coffea genotypes better adapted to low soil Pi availabilities, and the traits that contribute to improved $\mathrm{P}$ uptake and use efficiency. These data could be used to select current genotypes with improved $\mathrm{P}$ uptake or utilization efficiencies for use on soils with low Pi availability and also provide potential breeding material and targets for breeding new cultivars better adapted to the low Pi status of Brazilian soils. This could ultimately reduce the use of Pi fertilizers in tropical soils, and contribute to more sustainable coffee production.

Keywords: Coffea arabica, Coffea canephora, uptake, utilization, efficiency, phosphate, phosphorus 


\section{INTRODUCTION}

Brazilian coffee producing areas are concentrated in the tropical regions, whose soils are highly weathered with low plant available phosphate (Pi). Thus, Pi fertilizers are necessary to maintain crop production. Fertilizer Pi can be adsorbed by clay minerals or precipitated by iron $\left(\mathrm{Fe}^{2+}\right)$ and aluminum $\left(\mathrm{Al}^{3+}\right)$, which reduces the availability of $\mathrm{Pi}$ in tropical soil with only 10$20 \%$ of the Pi applied being absorbed by the crop (Mclaughlin et al., 1991; Bolland and Gilkes, 1998; Sousa and Lobato, 2003). Consequently, soil Pi availability can be a significant limiting factor in crop and coffee production (Vance et al., 2003; Lynch, 2007).

There are major concerns about the future availability of non-renewable phosphate rock reserves that could impact on $\mathrm{Pi}$ fertilizer availability and costs (Cordell et al., 2009; USGS, 2012). Thus, identification of economic and sustainable approaches that improve the efficiency of $\mathrm{Pi}$ fertilizer use are a high priority in crop breeding programs (Parentoni and Junior, 2008; Maia et al., 2011; Wiel et al., 2016). Since coffee breeding in the past has focused on breeding for high yields and pest and disease resistance under high soil fertility, there is scope and need to develop coffee cultivars for the future that are better adapted to low soil Pi availability.

Coffee has a high genetic variability and several studies indicate variation between different genotypes in relation to absorption and translocation of nutrients (Amaral et al., 2011), including zinc and P (Reis and Martinez, 2002), potassium, calcium, magnesium, and sulfur (Tomaz et al., 2003, 2008), boron, zinc, copper, and manganese (Tomaz et al., 2011), but few have explored $\mathrm{P}$ use efficiency. In research conducted by Martins et al. (2015), the authors indicated high genotypic variability for Coffea canephora genotypes cultivated in environments with low $\mathrm{Pi}$ availability in the soil and classified seven of the 13 cultivars studied as tolerant to low soil Pi availability.

Significant genetic variation has previously been observed in phosphorus use efficiency (PUE) related traits in plants (Wissuwa and Ae, 2001; Osborne and Rengel, 2002a,b; Ozturk et al., 2005; Gunes et al., 2006; Hammond et al., 2009). Genetic variation in PUE and related traits has previously been shown to be heritable (Fawole et al., 1982; Hammond et al., 2009) and once these traits have been identified in a cultivar, it could be used in breeding programs to improve crop PUE. Component traits that give rise to improved PUE are also identified through these studies and provide more focused breeding targets to achieve improved crop PUE (Hammond et al., 2009).

There are numerous definitions for PUE (White et al., 2005; Hammond et al., 2009; Rose and Wissuwa, 2012). Phosphorus (P) uptake efficiency refers to the plants ability to obtain $\mathrm{Pi}$ from the soil, and $\mathrm{P}$ utilization efficiency to the capacity for biomass production using the $\mathrm{P}$ absorbed (Wang et al., 2010). Increasing PUE can be achieved either by increasing uptake capacity or by optimizing its utilization (Manske et al., 2001; Shenoy and Kalagudi, 2005; Parentoni and Junior, 2008). The relative importance of each measure depends on the environmental conditions under which the crop is growing. In high input agri-ecosystems, the importance of $\mathrm{P}$ uptake efficiency is diminished, given the greater availability of Pi from fertilizer inputs. Improvements, in P utilization efficiency and reductions in the $\mathrm{P}$ removed at harvest would be of agronomic benefit under these conditions. In contrast, under low input systems, where soil $\mathrm{Pi}$ availability may be low, improvements in $\mathrm{P}$ acquisition and utilization are likely to be of benefit.

This study aims to quantify $\mathrm{P}$ uptake and use efficiency in cultivars of the species Coffea arabica L. and Coffea canephora L., group them in terms of efficiency and their response to $\mathrm{Pi}$ availability. This will identify genotypes and traits to support future breeding of coffee cultivars for low soil Pi conditions, reducing inputs and improving the sustainability of production.

\section{MATERIALS AND METHODS}

\section{Plant Material}

A total of 21 coffee cultivars of the species Coffea arabica L. and four cultivars of the species $C$. canephora (Supplementary Table 1) were grown under glasshouse conditions, in Piracicaba $\left(22^{\circ} 42^{\prime} 27.98^{\prime \prime} \mathrm{S}\right.$ and $47^{\circ} 37^{\prime} 58.21^{\prime \prime} \mathrm{W}$, altitude $\left.547 \mathrm{~m}\right)$, São Paulo State, Brazil, from July 2010 to August 2011. The materials were selected from the germplasm bank of the Instituto Agronômico de Campinas (IAC). C. arabica genetic material introduced to Brazil before the 1970's shows a narrow genetic base with high relationship between cultivars. Therefore, we also included exotic introductions from other countries, selections and botanical forms representing the two main species cultivated.

\section{Growth Conditions}

All seeds were germinated in washed sand and irrigated with deionized water. Seedlings were transplanted into $9 \mathrm{dm}^{3}$ pots (one seedling per pot) before the emergence of cotyledons. Pots were filled with soil, classified as Oxisol with medium texture, collected in Piracicaba, São Paulo State, at $20 \mathrm{~cm}$ below the surface to eliminate the effect of previous fertilizations (Supplementary Table 2). A low Pi treatment was used consisting of the original $\mathrm{Pi}$ concentration in the soil $\left(8 \mathrm{mg} \mathrm{Pi} \mathrm{dm}^{-3}\right.$ - resin extraction). The resin $\mathrm{Pi}$ extraction procedure was based upon ion exchange using an ion exchange resin to measure plant available Pi (Van Raij et al., 1986). A high Pi treatment was obtained by the addition of $3.7 \mathrm{~g}$ of monobasic ammonium phosphate $\left(\mathrm{NH}_{4} \mathrm{H}_{2} \mathrm{PO}_{4}\right)$ and $1.56 \mathrm{~g}$ monobasic potassium phosphate $\left(\mathrm{KH}_{2} \mathrm{PO}_{4}\right)$ per pot, to give a soil resin extractable Pi concentration of $120 \mathrm{mg} \mathrm{Pi} \mathrm{dm}^{-3}$, considered high for coffee production (Lani et al., 2007). In treatments without $\mathrm{Pi}, \mathrm{N}$ and $\mathrm{K}$ were added at each pot to ensure that all received the same amount $\left(1.28 \mathrm{~g} \mathrm{NH}_{4} \mathrm{NO}_{3}, 0.89 \mathrm{~g} \mathrm{~K}_{2} \mathrm{SO}_{4}\right.$, and $0.095 \mathrm{~g}$ $\mathrm{KCl})$. The limestone and fertilizers were mixed into the soil for each pot and incubated for 20 days, with moisture maintained at $60 \%$ of water retention capacity. Limestone was added to correct soil acidity. The remaining nutrients were provided in the following concentrations $\left(\mathrm{mg} \mathrm{dm}^{-3}\right): \mathrm{N}\left(\mathrm{NO}_{3}^{-}\right.$and $\left.\mathrm{NH}_{4}^{+}\right)$50; K-50; S-50; B-1; Co-0.1; Cu-1; Cl-5; Mn-5; Mo-0.15; Ni-0.1 and $\mathrm{Zn}-3$. Soil chemical and physical properties were determined prior to transplanting of seedlings (Supplementary Table 2). Basal $\mathrm{N}$ and $\mathrm{K}$ applications were supplemented with four applications in solution each month after plant emergence $\left(\mathrm{mg} \mathrm{dm}^{-3}\right)$ : N-50, 
K-50, and S-20. Pots were irrigated daily by means drip irrigation and the volume of water was calculated so that there was no runoff of water.

The experimental design consisted of randomized blocks, in a factorial design: 25 (cultivars) $\times 2$ (Pi concentrations: low and high $\mathrm{Pi}$ ), with five repetitions. Glasshouse average temperature was $23 \pm 3.35^{\circ} \mathrm{C}($ mean $\pm \mathrm{SD})$ and relative humidity $70 \% \pm 12.04$ (mean $\pm \mathrm{SD})$.

\section{Plant Analysis}

Plant height, stem diameter, and number of branches were measured every month. The height was obtained from the base to the apex of the orthotropic branch, and the stem diameter at $2 \mathrm{~cm}$ from the stem base. The orthotropic branch is the branch that grows vertically and supports the side branches. At harvest, 9 months after germination, the number of young and mature leaves, leaf area, and the dry mass of young leaves, mature leaves, branches, stem and roots were determined. Mature leaves were considered those fully expanded, with intense green color, and young leaves were considered as still expanding, with a pale green color. Leaf area was determined with a LiCor 3100 leaf area meter (LiCor, Nebraska, USA).

Plant material was rinsed in deionized water. Plagiotropic branches stem, and roots were dried in an oven with air circulation at $65^{\circ} \mathrm{C}$ for $72 \mathrm{~h}$. Plagiotropic branches are the reproductive side branches where the beans are produced. After drying, dry mass (DM) was obtained for each tissue, and the materials were finely milled in a Wiley mill.

\section{Phosphorus Concentration and P Content}

The $\mathrm{P}$ concentration in roots, stem, branches, mature, and young leaves were determined by X-ray fluorescence spectroscopy of dispersive energy (EDXRF). Briefly, $1 \mathrm{~g}$ of dried plant material was packed into a polyethylene cup of $20 \mathrm{~mm}$ internal diameter and covered with $6-\mu$ m-thick polypropylene film (Mylar $\left.{ }^{\circledR}\right)$. The samples were irradiated in triplicate for $300 \mathrm{~s}$ under vacuum using an energy dispersive X-ray fluorescence spectrometer (Shimadzu EDX-720, Shimadzu, Sao Paulo, SP, Brazil). The intensity of element $\mathrm{K} \alpha$ counts per second (cps/ $\mu \mathrm{A})$ was obtained from the sample X-ray spectrum deconvolution, and $\mathrm{P}$ concentration calculated, according methodology proposed by Tezotto et al. (2013). The P content was calculated using the P concentration and DM of each plant tissue.

\section{Phosphorus Use Efficiency}

The relative efficiency of phosphorus use (REP, \%) of cultivars was calculated as the ratio between the plant DM under low Pi and DM under high Pi, as described by Ozturk et al. (2005):

$$
R E P=\left(\frac{D M_{\text {low } P i}}{D M_{\text {high } P i}}\right) x 100
$$

The agronomic P use efficiency (APE, g DM g ${ }^{-1} \mathrm{Pi}$ ) was obtained by expression adapted from Oliveira et al. (1987):

$$
A P E=\frac{\left(D M_{\text {high } P i}-D M_{\text {low Pi }}\right)}{\begin{array}{l}
\text { difference in the total available Pi between } \\
\text { high Pi and low Pi treatments }
\end{array}}
$$

The APE and DM at low Pi were used to separate the cultivars into different categories, as described previously (Gerloff, 1977): (i) efficient and non-responsive cultivars (ENR); (ii) efficient and responsive cultivars (ER); (iii) non-efficient and responsive cultivars (NER); and (iv) non-efficient and non-responsive cultivars (NENR).

$\mathrm{P}$ use efficiency was separated into $\mathrm{P}$ uptake efficiency (PUpE, $\mathrm{mg} \mathrm{P} \mathrm{g}^{-1} \mathrm{Pi}$ ) and $\mathrm{P}$ utilization efficiency (PUtE, g DM g $\mathrm{g}^{-1} \mathrm{P}$ ). The PUpE was obtained by the ratio of $\mathrm{P}$ uptake in plant and the amount of $\mathrm{Pi}$ applied and PUtP represents the production of plant biomass per unit $\mathrm{P}$ accumulated in the plant:

$$
\begin{aligned}
& P U p E_{\text {high } P i}=\frac{\left([P]_{\text {high } P i} x D M_{\text {high } P i}\right)}{P i_{\text {applied }}} \text { or } \\
& P U p E_{\text {low } P i}=\frac{\left([P]_{\text {low } P i} x D M_{\text {low } P i}\right)}{P i_{\text {applied }}} \\
& P U t E_{\text {high } P i}=\frac{D M_{\text {high } P i}}{\left([P]_{\text {high } P i} x D M_{\text {high } P i}\right)} \text { or } \\
& P U t E_{\text {low } P i}=\frac{D M_{\text {low Pi }}}{\left([P]_{\text {low } i} x D M_{\text {low } P i}\right)}
\end{aligned}
$$

The physiological $\mathrm{P}$ use efficiency (PPUE, $\left(\mathrm{g}^{2} \mathrm{DM}_{\mathrm{g}} \mathrm{g}^{-1} \mathrm{P}\right)$ ) corresponds to DM produced for a given plant $\mathrm{P}$ concentration (Hammond et al., 2009).

$$
P P U E_{\text {high } P i}=\frac{D M_{\text {high } P i}}{[P]_{\text {high } P i}} \text { or PPUE } E_{\text {low } P i}=\frac{D M_{\text {low } P i}}{[P]_{\text {low } P i}}
$$

\section{Statistical Analyses}

Data were analyzed by analysis of variance using SAS (SAS Institute INC., Cary, NC, USA) and means were compared by Tukey test at $P<0.05$. The relationship between dry mass and relative efficiency of $\mathrm{P}$ were analyzed by regression analysis. Correlations between the measured data were performed using the Pearson correlation coefficient in GenStat (64-bit Release 16.1, VSN International Ltd., Hemel Hempstead, UK). Significant correlations were identified at a significance level of $P<0.05$.

\section{RESULTS}

\section{Low Pi Availability Reduces Coffee Growth and Development}

Coffee plants grown at low Pi showed symptoms of nutrient deficiency. As the Pi deficiency progressed, mature leaves became chlorotic with necrotic lesions on the leaf apex, as observed by Ozturk et al. (2005). Total plant dry mass (DM) was reduced by approximately 50\% under low Pi conditions compared to high $\mathrm{Pi}$ conditions and the greatest DM reduction was observed in the branches that accumulated only $43 \%$ of the DM at high Pi (Table 1). Cultivars of $C$. canephora produced more DM in the roots, regardless of the $\mathrm{Pi}$ treatment, compared to cultivars of C. arabica. Consequently, cultivars of $C$. canephora had higher root/shoot ratios (Table 1). Growth rates of plants at high Pi were higher than those at low Pi until the 5th month for C. arabica and the 6th month for C. canephora (Supplementary Table 3). After this period, growth rates were similar regardless of the $\mathrm{Pi}$ 
TABLE 1 | Means of dry mass of shoot and roots and ratio root/shoot of 21 cultivars of $C$. arabica and 4 cultivars of $C$. canephora.

\begin{tabular}{|c|c|c|c|c|c|}
\hline P Treatment & Species & $\operatorname{Root}(g)^{a}$ & Shoot $(g)^{a, b}$ & Total $(\mathbf{g})^{a}$ & Ratio \\
\hline & & & & & Root/Shoot ${ }^{a}$ \\
\hline \multirow[t]{2}{*}{ Low Pi } & C. arabica & $6.2 \mathrm{Bb}$ & 23.0 Ba & $29.3 \mathrm{Bb}$ & $0.27 \mathrm{Ab}$ \\
\hline & C. canephora & $7.3 \mathrm{Ba}$ & $18.0 \mathrm{Bb}$ & $25.4 \mathrm{Bb}$ & $0.40 \mathrm{Aa}$ \\
\hline \multirow[t]{2}{*}{ High Pi } & C. arabica & $10.9 \mathrm{Ab}$ & $37.9 \mathrm{Aa}$ & 49.2 Aa & $0.29 \mathrm{Ab}$ \\
\hline & C. canephora & $13.4 \mathrm{Aa}$ & $32.8 \mathrm{Aa}$ & 46.3 $\mathrm{Aa}$ & $0.43 \mathrm{Aa}$ \\
\hline F-test: & & $54.9^{*}$ & $60.4^{*}$ & $62.7^{*}$ & $22.0^{*}$ \\
\hline Species (S) & & $31.3^{\star}$ & $15.1^{*}$ & $2.56^{\mathrm{ns}}$ & $145.8^{*}$ \\
\hline Level of $P(P)$ & & $230.0^{*}$ & $208.0^{\star}$ & $222.5^{\star}$ & $0.0^{\mathrm{ns}}$ \\
\hline$S \times P$ interaction: & & $6.5^{\star}$ & $0.7^{\mathrm{ns}}$ & $0.2^{\mathrm{ns}}$ & $1.0^{\mathrm{ns}}$ \\
\hline
\end{tabular}

a Values followed by the same capital letters vertically do not differ significantly $(P>0.05)$ between treatments (low and high Pi) and values followed by the same lowercase letters do not differ significantly $(P>0.05)$ between species (C. arabica and C. canephora). ${ }^{b}$ Shoot $=$ stem + branches + mature leaves + young leaves.

* significant effect; ns, not significant.

supply. The growth rate reduced after 6 months in both species in both Pi supplies, due to temperature reduction after April. Plant height of C. arabica was superior to that of C. canephora 9 months after emergence, at both Pi supplies (Figure 1). At the end of the experiment, the cultivars of $C$. arabica showed, on average, between 4 and 5 pairs of branches, while cultivars of $C$. canephora had two pairs of branches, attributed to the genetic characteristics of these species.

\section{Coffee Plant P Concentration was Greater in Cultivars of C. canephora}

Highest plant $\mathrm{P}$ concentration and content occurred in plants supplied with high $\mathrm{Pi}$ (Table 2). Average plant $\mathrm{P}$ concentrations were higher in $C$. canephora species, at both low and high Pi. Plant $\mathrm{P}$ content did not differ significantly between the species in low $\mathrm{Pi}$, but it was significantly higher in plants of $C$. canephora at high Pi.

There was significant variation in plant $\mathrm{P}$ concentration and $\mathrm{P}$ content among the cultivars (Table 2). The $\mathrm{P}$ concentration ranged from $0.61 \mathrm{~g} \mathrm{~kg}^{-1}$ (E22 Sídamo) to $0.90 \mathrm{~g} \mathrm{~kg}^{-1}$ (Apoatã) in low $\mathrm{P}$, and from $1.03 \mathrm{~g} \mathrm{~kg}^{-1}$ (E22 Sídamo) to $1.96 \mathrm{~g} \mathrm{~kg}^{-1}$ (Guarini) at high Pi. In turn, P content ranged from $14.8 \mathrm{~g}$ plant $^{-1}$ (Catuaí Amarelo) to $25.7 \mathrm{~g} \mathrm{plant}^{-1}$ (Geisha) in low Pi, and from 49.2 g plant $^{-1}$ (Obatã) to 92.3 g plant $^{--1}$ (Guarini) in high $\mathrm{P}$, with an increase of between 160 and 459\% with Pi supply (Table 2).

Young leaves showed on average the highest $\mathrm{P}$ concentration, followed by mature leaves, stem + branches and roots, in both species at both Pi supplies. Phosphorus concentrations in plant tissues varied significantly among the cultivars. At low Pi, P concentration in roots ranged from $0.43 \mathrm{~g} \mathrm{~kg}^{-1}$ (Catuaí Amarelo) to $0.60 \mathrm{~g} \mathrm{~kg}^{-1}$ (Acaiá), stem + branches from $0.43 \mathrm{~g} \mathrm{~kg}^{-1}$ (Geisha) to $0.89 \mathrm{~g} \mathrm{~kg}^{-1}$ (Apoatã); in mature leaves from $0.62 \mathrm{~g} \mathrm{~kg}^{-1}$ (Acaiá) to $0.99 \mathrm{~g} \mathrm{~kg}^{-1}$ (Guarini) and in young leaves from 0.91 $\mathrm{g} \mathrm{kg}^{-1}$ (E22 Sídamo, Tupi) to $1.85 \mathrm{~g} \mathrm{~kg}^{-1}$ (Guarini). At high $\mathrm{Pi}, \mathrm{P}$ concentration in roots ranged from $0.73 \mathrm{~g} \mathrm{~kg}^{-1}$ (Bourbon Vermelho, Geisha, E208 Ilubabor) to $1.00 \mathrm{~g} \mathrm{~kg}^{-1}$ (Bukobensis),

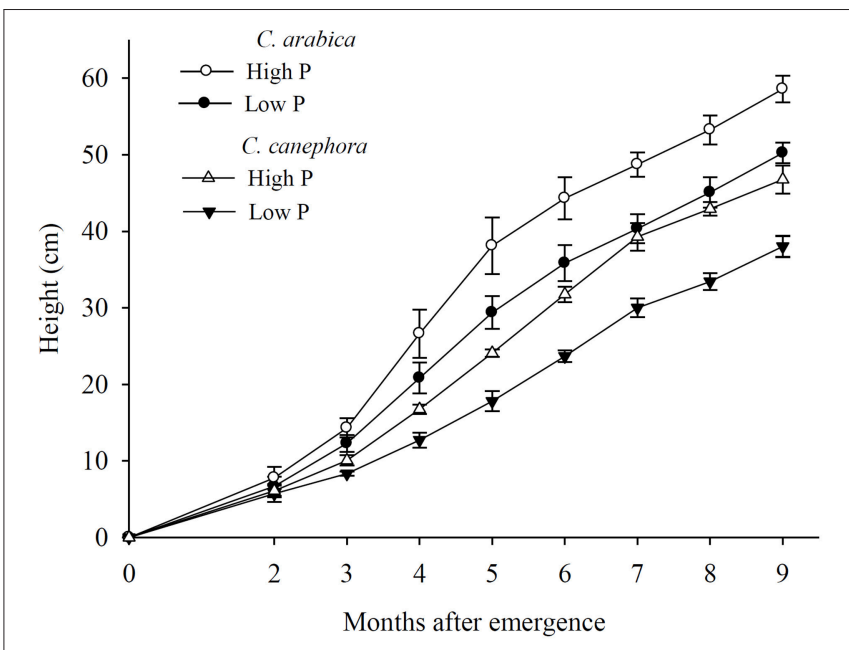

FIGURE 1 | Average height of seedlings of Coffea arabica (circles) and C. canephora (triangles) grown at low $P\left(8 \mathrm{mg} \mathrm{dm}^{-3}\right.$ resin $\mathrm{P}$, closed symbols) and high $P$ (120 $\mathrm{mg} \mathrm{dm}^{-3}$ resin $P$, open symbols). Plants were grown under glasshouse conditions from July 2010 to August 2011 in Piracicaba, São Paulo State, Brazil. Plant height was measured from the base to the apex of the orthotropic branch.

stem+branches from $0.73 \mathrm{~g} \mathrm{~kg}^{-1}$ (E22 Sídamo) to $2.28 \mathrm{~g} \mathrm{~kg}^{-1}$ (Guarini), in mature leaves from $1.17 \mathrm{~g} \mathrm{~kg}^{-1}$ (E22 Sídamo) to 2.14 $\mathrm{g} \mathrm{kg}^{-1}$ (Guarini) and in young leaves from $1.68 \mathrm{~g} \mathrm{~kg}^{-1}$ (Geisha) to $2.96 \mathrm{~g} \mathrm{~kg}^{-1}$ (Guarini; Table 3).

\section{Coffee Cultivars Vary in Their P Utilization - C. canephora is More Efficient in P Uptake and $\mathbf{C}$. arabica is More Efficient in $\mathbf{P}$ Utilization}

The relative efficiency (REP) in biomass accumulation, obtained by the ratio between $\mathrm{DM}$ at low $\mathrm{Pi}$ and $\mathrm{DM}$ at high $\mathrm{Pi}$, was $61 \%$ on average for cultivars of C. arabica and 55\% on average for cultivars of C. canephora (Table 4). The variation between genotypes for DM ranged from $18.9 \mathrm{~g} \mathrm{plant}^{-1}$ for cultivar Guarani to $41 \mathrm{~g} \mathrm{plant}^{-1}$ for cultivar Geisha at low Pi and 39.8 $\mathrm{g}$ plant ${ }^{-1}$ for cultivar Obatã to $55.4 \mathrm{~g} \mathrm{plant}^{-1}$ for cultivar E 16 Shoa at high $\mathrm{Pi}$.

The allocation into different groups of efficiency and response to $\mathrm{Pi}$ is based on the $\mathrm{DM}$ of the plants at low $\mathrm{Pi}$ (axis $\mathrm{x}$ ) and agronomic $\mathrm{P}$ use efficiency (APE) index (axis y) of each cultivar (Gerloff, 1977). The average DM production of nonefficient cultivars was $25.2 \mathrm{~g}$ in low $\mathrm{Pi}$, while efficient cultivars produced on average $31.8 \mathrm{~g}$ of $\mathrm{DM}$ in the same condition. The average APE for responsive cultivars was $24.27 \mathrm{~g} \mathrm{DM}$ $\mathrm{g}^{-1} \mathrm{P}$, while the average for non-responsive cultivars was $15.99 \mathrm{~g} \mathrm{DM} \mathrm{g}^{-1} \mathrm{P}$. Of the 25 lines studied, only four $C$. arabica lines were classified as being efficient and responsive (Figure 2).

The $\mathrm{P}$ uptake and utilization efficiency varied significantly between genotypes. The PUpE, $\mathrm{P}$ taken up per unit of available $\mathrm{Pi}$, was higher in plants grown under low Pi. Cultivars of $C$. canephora showed higher PUpE compared to C. arabica in both 
TABLE 2 | Plant P concentration and P content in coffee cultivars grown at low and high $\mathrm{Pi}$.

\begin{tabular}{|c|c|c|c|c|}
\hline \multirow[t]{2}{*}{ Cultivars } & \multicolumn{2}{|c|}{$\begin{array}{l}\text { P concentration } \\
\text { (g P kg-1 DM) }\end{array}$} & \multicolumn{2}{|c|}{$\begin{array}{c}\text { P content } \\
\left(\text { mg plant }^{-1}\right)\end{array}$} \\
\hline & Low Pi & High Pi & Low $\mathrm{Pi}$ & High Pi \\
\hline \multicolumn{5}{|l|}{ Coffea arabica } \\
\hline Typica & 0.62 & 1.28 & 15.3 & 68.0 \\
\hline Bourbon Vermelho & 0.65 & 1.07 & 15.9 & 55.9 \\
\hline Bourbon Amarelo & 0.66 & 1.12 & 21.5 & 55.8 \\
\hline Mundo Novo & 0.64 & 1.29 & 17.7 & 70.3 \\
\hline Acaiá & 0.63 & 1.18 & 19.3 & 61.4 \\
\hline Caturra Vermelho & 0.74 & 1.42 & 22.0 & 67.9 \\
\hline Caturra Amarelo & 0.70 & 1.46 & 21.5 & 64.6 \\
\hline Catuaí Vermelho & 0.69 & 1.35 & 20.1 & 60.6 \\
\hline Catuaí Amarelo & 0.66 & 1.40 & 14.8 & 64.8 \\
\hline Icatu Precoce & 0.63 & 1.20 & 21.5 & 61.7 \\
\hline Ouro Verde & 0.82 & 1.39 & 21.6 & 62.1 \\
\hline Obatã & 0.69 & 1.24 & 18.4 & 49.2 \\
\hline Tupi & 0.65 & 1.34 & 19.3 & 65.3 \\
\hline E 534 Kaffa & 0.66 & 1.18 & 16.9 & 62.7 \\
\hline E 208 Illubabor & 0.68 & 1.05 & 19.1 & 50.6 \\
\hline E 22 Sidamo & 0.61 & 1.03 & 18.1 & 54.8 \\
\hline E 16 Shoa & 0.64 & 1.17 & 19.4 & 64.8 \\
\hline E 12 Harar & 0.65 & 1.14 & 22.7 & 60.5 \\
\hline Jimma Tane & 0.69 & 1.22 & 15.9 & 53.0 \\
\hline Geisha & 0.63 & 1.06 & 25.7 & 51.9 \\
\hline lemen & 0.64 & 1.19 & 20.0 & 63.5 \\
\hline Average $^{a}$ & $0.67 \mathrm{Bb}$ & $1.23 \mathrm{Ab}$ & $19.4 \mathrm{Ba}$ & $60.4 \mathrm{Ab}$ \\
\hline \multicolumn{5}{|l|}{ Coffea canephora } \\
\hline Apoatã & 0.90 & 1.92 & 23.0 & 86.4 \\
\hline Robusta & 0.77 & 1.60 & 22.0 & 77.0 \\
\hline Bukobensis & 0.83 & 1.45 & 22.8 & 63.5 \\
\hline Guarini & 0.88 & 1.96 & 16.5 & 92.3 \\
\hline Average $^{a}$ & $0.85 \mathrm{Ba}$ & $1.74 \mathrm{Aa}$ & $21.1 \mathrm{Ba}$ & 79.8Aa \\
\hline F-test: 19,89 & \multicolumn{2}{|c|}{$29.58^{\star}$} & \multicolumn{2}{|c|}{$16.18^{\star}$} \\
\hline Cultivars (C): & \multicolumn{2}{|c|}{$12.32^{*}$} & \multicolumn{2}{|c|}{$1.78^{\star}$} \\
\hline Level of $\mathrm{P}(\mathrm{P})$ & \multicolumn{2}{|c|}{$1172.40^{*}$} & \multicolumn{2}{|c|}{$746.92^{*}$} \\
\hline Interaction $\mathrm{C} \times \mathrm{P}$ & \multicolumn{2}{|c|}{$3.83^{*}$} & \multicolumn{2}{|c|}{$1.72^{\star}$} \\
\hline Least significant difference: & 0.14 & 0.45 & 10.3 & 40.6 \\
\hline
\end{tabular}

a Values followed by the same capital letters do not differ significantly $(P>0.05)$ between treatments and values followed by the same lowercase letters do not differ significantly $(P>0.05)$ between species.

Pi treatments (Table 5). The PUpE ranged from $206 \mathrm{mg} \mathrm{P} \mathrm{g}^{-1} \mathrm{Pi}$ (cv. Catuaí Yellow) to $319 \mathrm{mg} \mathrm{P} \mathrm{g}^{-1} \mathrm{Pi}$ (Apoatã) at low Pi and between $46 \mathrm{mg} \mathrm{P} \mathrm{g}^{-1} \mathrm{Pi}$ (Obatã) and $85 \mathrm{mg} \mathrm{P} \mathrm{g}^{-1} \mathrm{Pi}$ (Guarini) at high Pi (Table 5). The PUtE was higher in plants of C. arabica in both Pi treatments. At low Pi PUtE ranged from $1.12 \mathrm{~g} \mathrm{DM} \mathrm{mg}^{-1}$ $\mathrm{P}$ (Apoatã) to $1.66 \mathrm{~g} \mathrm{DM} \mathrm{mg}^{-1} \mathrm{P}$ (E22 Sidamo), and at high Pi, from $0.52 \mathrm{~g} \mathrm{DM} \mathrm{mg}^{-1} \mathrm{P}$ (Guarini) to $0.97 \mathrm{~g} \mathrm{DM} \mathrm{mg}^{-1} \mathrm{P}$ (E22 Sidamo; Table 5).

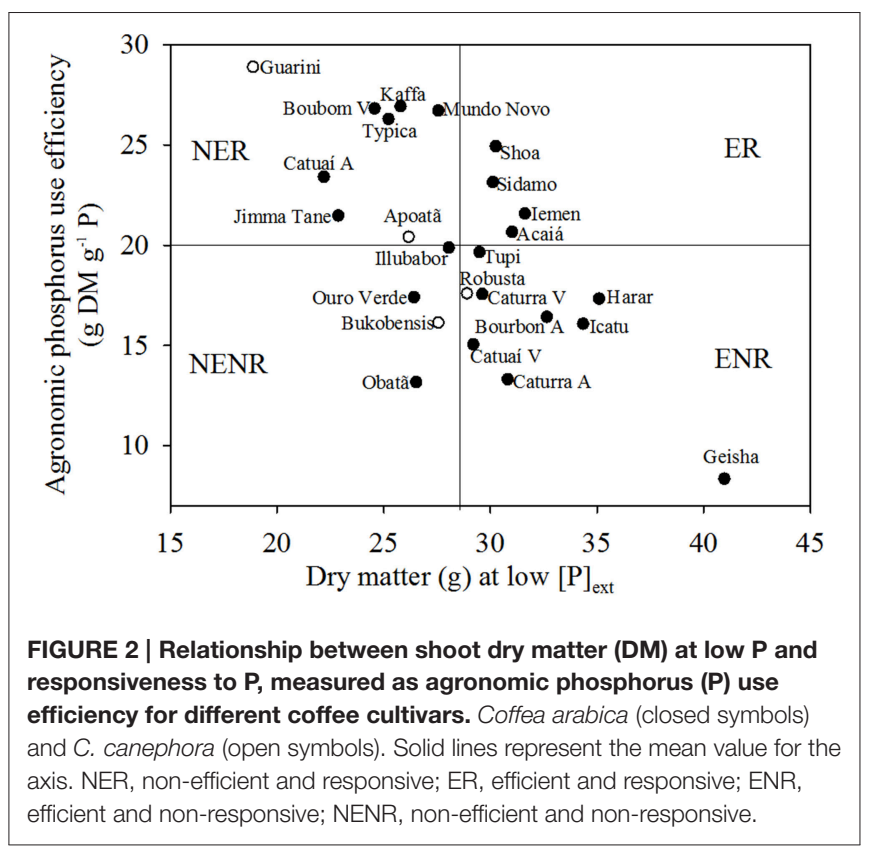

PPUE was higher in plants grown under Pi deficiency due to the reduced availability and uptake of Pi. Further, PPUE was higher in plants of the species C. arabica under both $\mathrm{Pi}$ treatments. PPUE varied among genotypes, ranging from 21.3 (Guarini) to $64.9 \mathrm{~g}^{2} \mathrm{DM} \mathrm{mg}^{-1} \mathrm{P}$ (Geisha) at low $\mathrm{Pi}$, and from 24.4 (Guarini) to $51.6 \mathrm{~g}^{2} \mathrm{DM} \mathrm{mg}^{-1} \mathrm{P}$ (E22 Sidamo) under high Pi (Table 5).

Significant correlations between biomass, P uptake and measures of PUE were observed within treatments (Supplementary Table 4). At low $\mathrm{Pi}$, significant positive correlations between PPUE and the P content of shoots, mature leaves and stems was observed, but no significant correlations were observed between PPUE and the P content of young leaves or roots. At low $\mathrm{Pi}$, the root to shoot ratio was significantly $(P=$ $0.0012)$ positively correlated with PUpE, but significantly $(P=$ $<0.001)$ negatively correlated with PUtE. Root to shoot ratio was also significantly positively correlated with aboveground tissue $\mathrm{P}$ concentrations under both low and high Pi supplies. Root to shoot ratio was significantly $(P=<0.001)$ negatively correlated with both PUtE and PPUE under high Pi supply (Supplementary Table 4B).

\section{DISCUSSION}

In the current study, we assessed 21 cultivars of $C$. arabica and four cultivars of $C$. canephora and observed a wide variation of different components of PUE and growth traits in response to soil Pi availability. Interestingly, at the species level, cultivars of $C$. canephora showed higher PUpE compared to C. arabica in both $\mathrm{Pi}$ treatments and cultivars of $C$. arabica showed higher PUtE compared to C. canephora in both Pi treatments (Table 5). Root to shoot ratios of coffee cultivars were also positively correlated with PUpE at low soil Pi availability, but negatively correlated with PUtE (Supplementary Table 4). 
TABLE 3 | P concentration in roots, stem+branches, mature leaves, and young leaves of coffee cultivars in low and high P.

\begin{tabular}{|c|c|c|c|c|c|c|c|}
\hline \multicolumn{2}{|c|}{ Roots } & \multicolumn{2}{|c|}{ Stem+branches } & \multicolumn{2}{|c|}{ Mature leaves } & \multicolumn{2}{|c|}{ Young leaves } \\
\hline Low Pi & High Pi & Low Pi & High Pi & Low Pi & High Pi & Low Pi & High Pi \\
\hline
\end{tabular}

\begin{tabular}{|c|c|c|c|c|c|c|c|c|}
\hline \multicolumn{9}{|l|}{ Coffea arabica } \\
\hline Typica & 0.49 & 0.74 & 0.47 & 1.10 & 0.67 & 1.59 & 0.95 & 1.88 \\
\hline Bourbon V. & 0.56 & 0.73 & 0.49 & 0.79 & 0.71 & 1.34 & 0.95 & 1.97 \\
\hline Bourbon A. & 0.53 & 0.78 & 0.47 & 0.80 & 0.73 & 1.34 & 1.07 & 1.87 \\
\hline Mundo Novo & 0.54 & 0.89 & 0.46 & 0.97 & 0.68 & 1.69 & 1.04 & 1.88 \\
\hline Acaiá & 0.60 & 0.95 & 0.46 & 0.81 & 0.62 & 1.50 & 0.99 & 1.91 \\
\hline Caturra V. & 0.55 & 0.92 & 0.53 & 1.24 & 0.8 & 1.69 & 1.14 & 1.99 \\
\hline Caturra A. & 0.54 & 0.87 & 0.53 & 1.16 & 0.75 & 1.78 & 1.11 & 2.26 \\
\hline Catuaí V. & 0.51 & 0.86 & 0.51 & 1.14 & 0.75 & 1.48 & 1.13 & 2.03 \\
\hline Catuaí A. & 0.43 & 0.82 & 0.50 & 1.16 & 0.71 & 1.74 & 1.08 & 2.06 \\
\hline Icatu Precoce & 0.52 & 0.79 & 0.46 & 0.83 & 0.69 & 1.54 & 0.99 & 2.04 \\
\hline Ouro Verde & 0.60 & 0.94 & 0.62 & 1.16 & 0.85 & 1.56 & 1.27 & 2.13 \\
\hline Obatã & 0.51 & 0.82 & 0.53 & 1.03 & 0.71 & 1.31 & 1.06 & 1.90 \\
\hline Tupi & 0.55 & 0.86 & 0.57 & 1.37 & 0.63 & 1.40 & 0.91 & 1.91 \\
\hline E 534 Kaffa & 0.53 & 0.96 & 0.46 & 0.97 & 0.72 & 1.35 & 1.14 & 1.93 \\
\hline E 208 Illubabor & 0.53 & 0.73 & 0.48 & 0.80 & 0.78 & 1.25 & 1.12 & 1.81 \\
\hline E 22 Sidamo & 0.50 & 0.81 & 0.49 & 0.73 & 0.63 & 1.17 & 0.91 & 1.79 \\
\hline E 16 Shoa & 0.51 & 0.90 & 0.45 & 0.87 & 0.75 & 1.42 & 1.02 & 1.96 \\
\hline E 12 Harar & 0.54 & 0.87 & 0.45 & 0.90 & 0.75 & 1.41 & 1.06 & 1.74 \\
\hline Jimma Tane & 0.46 & 0.86 & 0.55 & 0.96 & 0.72 & 1.43 & 1.27 & 1.93 \\
\hline Geisha & 0.56 & 0.73 & 0.43 & 0.85 & 0.74 & 1.24 & 1.07 & 1.68 \\
\hline lemen & 0.50 & 0.81 & 0.48 & 1.08 & 0.74 & 1.38 & 1.05 & 1.88 \\
\hline \multirow[t]{2}{*}{ Average $^{a}$} & 0.53 & 0.84 & 0.49 & 0.99 & 0.72 & 1.46 & 1.06 & 1.93 \\
\hline & $\mathrm{Ba}$ & $\mathrm{Ab}$ & $\mathrm{Bb}$ & $\mathrm{Ab}$ & $\mathrm{Bb}$ & $\mathrm{Ab}$ & $\mathrm{Bb}$ & $\mathrm{Ab}$ \\
\hline \multicolumn{9}{|l|}{ Coffea canephora } \\
\hline Apoatã & 0.51 & 0.97 & 0.89 & 2.20 & 0.95 & 2.01 & 1.68 & 2.91 \\
\hline Robusta & 0.50 & 0.85 & 0.74 & 1.87 & 0.88 & 1.88 & 1.25 & 2.46 \\
\hline Bukobensis & 0.57 & 1.00 & 0.84 & 1.81 & 0.80 & 1.42 & 1.63 & 2.32 \\
\hline Guarini & 0.49 & 0.97 & 0.67 & 2.28 & 0.99 & 2.14 & 1.85 & 2.96 \\
\hline \multirow[t]{2}{*}{ Average $^{a}$} & 0.52 & 0.95 & 0.79 & 2.04 & 0.91 & 1.86 & 1.60 & 2.66 \\
\hline & $\mathrm{Ba}$ & $\mathrm{Aa}$ & $\mathrm{Ba}$ & $\mathrm{Aa}$ & $\mathrm{Ba}$ & $\mathrm{Aa}$ & $\mathrm{Ba}$ & $\mathrm{Aa}$ \\
\hline$F$-test: & \multicolumn{2}{|c|}{$15.98^{\star}$} & \multicolumn{2}{|c|}{$31.54^{*}$} & \multicolumn{2}{|c|}{$17.29^{*}$} & \multicolumn{2}{|c|}{$22.58^{\star}$} \\
\hline Cultivars (C) & \multicolumn{2}{|c|}{$252.00^{\star}$} & \multicolumn{2}{|c|}{$26.14^{\star}$} & \multicolumn{2}{|c|}{$4.92^{\star}$} & \multicolumn{2}{|c|}{$11.60^{\star}$} \\
\hline Level of $P(P)$ & \multicolumn{2}{|c|}{$711.71^{\star}$} & \multicolumn{2}{|c|}{$802.33^{*}$} & \multicolumn{2}{|c|}{$745.68^{*}$} & \multicolumn{2}{|c|}{$868.11^{*}$} \\
\hline $\mathrm{C} \times \mathrm{P}$ interaction: & \multicolumn{2}{|c|}{$1.66^{*}$} & \multicolumn{2}{|c|}{$9.55^{\star}$} & \multicolumn{2}{|c|}{$1.88^{*}$} & \multicolumn{2}{|c|}{$1.81^{*}$} \\
\hline Least significant difference & 0.17 & 0.27 & 0.19 & 0.53 & 0.18 & 0.72 & 0.39 & 0.74 \\
\hline
\end{tabular}

${ }^{a}$ Values followed by the same capital letters do not differ significantly $(P>0.05)$ between treatments and values followed by the same lowercase letters do not differ significantly $(P>$ 0.05) between species.

The coffee varieties differed in growth and DM production in low Pi and in response to Pi supply (Table 4). The REP among the cultivars ranged from 39 (cv Guarini) to 83\% (cv Geisha), i.e., the DM production in low Pi in cultivar Guarini was greatly reduced, while in Geisha, there was a slight reduction in DM between high and low Pi treatments (Table 4). Previous breeding efforts have focused on increasing grain or DM production.
Since these are used in all indexes to calculate $\mathrm{P}$ utilization efficiencies, increased grain or DM biomass with or without changes in $\mathrm{P}$ concentrations in tissues can result in unintentional improvements in PUE (Hammond et al., 2009). The genotypes with greater REP indexes produced more biomass under low $\mathrm{Pi}$, which indicates that DM under low $\mathrm{Pi}$ is a good parameter for studies on P efficiency, which was also observed by Ozturk et al. 
TABLE 4 | Dry mass (DM), relative efficiency $P$ (REP), and agronomic $P$ use efficiency (APE) of 25 cultivars and their respective groups: efficient responsive (ER), efficient non-responsive (ENR), non-efficient responsive (NER) and non-efficient non-responsive (NENR) defined in Figure 2.

\begin{tabular}{|c|c|c|c|c|}
\hline \multirow[t]{2}{*}{ Cultivars } & \multicolumn{2}{|c|}{ Dry mass (g plant ${ }^{-1}$ ) } & \multirow[t]{2}{*}{ REP (\%) } & \multirow{2}{*}{ 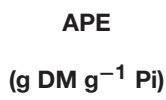 } \\
\hline & Low Pi & High Pi & & \\
\hline \multicolumn{5}{|l|}{ ER } \\
\hline E 16 Shoa & 30.25 & 55.39 & 55 & 24.94 \\
\hline E 22 Sidamo & 30.12 & 53.45 & 56 & 23.15 \\
\hline lemen & 31.62 & 53.37 & 59 & 21.58 \\
\hline Acaiá & 31.02 & 51.84 & 60 & 20.66 \\
\hline \multicolumn{5}{|l|}{ ENR } \\
\hline Tupi & 29.49 & 49.30 & 60 & 19.65 \\
\hline Robusta & 28.90 & 46.64 & 62 & 17.6 \\
\hline Caturra Vermelho & 29.62 & 47.33 & 63 & 17.57 \\
\hline E 12 Harar & 35.09 & 52.56 & 67 & 17.33 \\
\hline Bourbon Amarelo & 32.65 & 49.22 & 66 & 16.43 \\
\hline Icatu Precoce & 34.34 & 50.55 & 68 & 16.08 \\
\hline Catuaí Vermelho & 29.20 & 44.38 & 66 & 15.05 \\
\hline Caturra Amarelo & 30.81 & 44.23 & 70 & 13.31 \\
\hline Geisha & 40.97 & 49.39 & 83 & 8.36 \\
\hline \multicolumn{5}{|l|}{ NER } \\
\hline Guarini & 18.88 & 48.00 & 39 & 28.89 \\
\hline E 534 Kaffa & 25.79 & 52.93 & 49 & 26.93 \\
\hline Bourbon Vermelho & 24.58 & 51.62 & 48 & 26.83 \\
\hline Mundo Novo & 27.56 & 54.48 & 51 & 26.71 \\
\hline Typica & 25.22 & 51.73 & 49 & 26.29 \\
\hline Catuaí Amarelo & 22.20 & 45.80 & 48 & 23.41 \\
\hline Jimma Tane & 22.88 & 44.53 & 51 & 21.48 \\
\hline Apoatã & 26.17 & 46.76 & 56 & 20.42 \\
\hline \multicolumn{5}{|l|}{ NENR } \\
\hline E 208 Illubabor & 28.05 & 48.09 & 58 & 19.88 \\
\hline Ouro Verde & 26.42 & 43.97 & 60 & 17.41 \\
\hline Bukobensis & 27.56 & 43.84 & 63 & 16.14 \\
\hline Obatã & 26.53 & 39.81 & 67 & 13.17 \\
\hline $\begin{array}{l}\text { Average-Reference } \\
\text { values of Figure } \mathbf{2}\end{array}$ & 28.64 & & & 19.28 \\
\hline
\end{tabular}

REP was calculated as ([DM Low Pi/DM High Pi] $\times$ 100). APE was calculated how ([DM High Pi $-D M_{\text {Low Pi }}$ /difference in total Pi availability between high Pi and low Pi

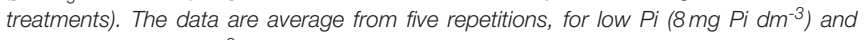
high Pi (120 mg Pi dm $\left.{ }^{-3}\right)$.

(2005) in wheat genotypes. However, DM or grain production is not sufficient for the understanding of processes that determine the PUEs of plants or of the capacity of the plant to grow productively under low Pi availability.

Using the biomass response of plants to $\mathrm{Pi}$ availability, plants can be grouped into "efficient" and "inefficient" based on the ability of cultivars to convert nutrients into dry matter (Vose, 1987). Furthermore, they may be grouped as "responsive" and "non-responsive" based on the plants biomass response to the addition of the nutrient (Fageria and Baligar, 1993), with plants having above average APE values grouped as "responsive" and plants having below average APE values grouped as "non-responsive" (Figure 2). Gerloff (1977) conducted the first study classifying plants into four groups in terms of efficiency and response to nutrient supply: (i) efficient and responsive plants that produce above average biomass at lower nutrient concentrations and respond to nutrient addition; (ii) inefficient and responsive-plants that produce less than average biomass at lower nutrient concentrations but still respond to nutrient addition; (iii) efficient and non-responsive-plants that produce above average biomass at lower nutrient concentrations, but do not respond to the addition of nutrients; (iv) inefficient and nonresponsive-plants that produce less than average biomass at lower nutrient concentrations, which do not respond to nutrient addition. This is the first study to use these criteria to characterize coffee cultivars for their efficient use of available $\mathrm{Pi}$ and response to the addition of Pi. It clearly identifies four cultivars that are efficient and responsive to Pi supply, all of which are C. arabica. These varieties are most likely to perform well under low $\mathrm{Pi}$ conditions and would provide useful genetic material in the breeding of new varieties with improved PUE.

Among the DM parameters, the root DM showed a significant difference between species. Plants of $C$. canephora have a longer root system, in both conditions of $\mathrm{P}$ supply (Table 1), which may explain the increased $\mathrm{P}$ uptake efficiency in the genotypes of this species (Table 5). This species has a more robust and vigorous root system, the reason why it is often used as a graft for plants of $C$. arabica. The evolution of $C$. canephora exposed to sunlight and in a region with an average temperature of $23^{\circ} \mathrm{C}$ led to greater development of the root system to provide more water for transpiration to regulate leaf temperature. Another aspect that reinforces this statement is the presence of twice as many stomata per square millimeter of leaf area in relation to cultivars of C. arabica (Voltan et al., 1992). Phosphate movement through the soil to the root surface is governed by diffusion, rather than mass flow. In low Pi soils, cultivars that have a larger root system are more likely to intercept and acquire $\mathrm{P}$, as occurred with the cultivars of $C$. canephora. This is also reflected in the significant positive correlation between root to shoot ratio and aboveground tissue P concentrations (Supplementary Table 4).

Low soil $\mathrm{Pi}$ availability resulted in a significant reduction of $\mathrm{P}$ concentration and content of the tissues studied. The $\mathrm{P}$ concentration in the roots, stem+branches, mature leaves and young leaves under low Pi were 40-60\% lower when compared to high Pi supply. The P content was $20-40 \%$ lower under low $\mathrm{Pi}$ when compared to high Pi supply.

Cultivars of C. canephora showed higher P concentration in tissues, in both Pi treatments (Table 2), which can be explained by the greater efficiency of Pi uptake by $C$. canephora cultivars under both high and low Pi (Table 5). Of the total P accumulated by cultivars of $C$. arabica under low Pi supply, $36 \%$ was in mature leaves, $26 \%$ in young leaves, $21 \%$ in stem+branches and $17 \%$ in the roots. The total $\mathrm{P}$ accumulated in C. canephora under low $\mathrm{P}$ supply was $43 \%$ in mature leaves, $20 \%$ in young leaves, $19 \%$ in stem+branches and $18 \%$ in roots. While the young and growing tissues are the main sinks for $\mathrm{P}$, mature leaves still contain a significant proportion of $\mathrm{P}$ accumulated by coffee, with about $40 \%$ of accumulated $\mathrm{P}$, even under conditions of $\mathrm{P}$ deficiency. Bragança et al. (2008) observed P contents of 33\% in stem+ 
TABLE 5 | P uptake (PUpE) (g P g $\mathrm{g}^{-1} \mathrm{Pi}$ ) and $\mathrm{P}$ utilization efficiency (PUtE) (g DM $\mathrm{g}^{-1} \mathrm{P}$ ) and physiological $\mathrm{P}$ use efficiency (PPUE) ( ${ }^{2}$ DM mg $\left.{ }^{-1} \mathrm{P}\right)$ of 25 coffee cultivars grown at low and high $\mathrm{Pi}$.

\begin{tabular}{|c|c|c|c|c|c|c|}
\hline \multirow[t]{2}{*}{ Cultivars } & \multicolumn{2}{|c|}{$\begin{array}{c}\text { PUpE } \\
\left(\mathrm{mg} \mathrm{P} \mathrm{g}^{-1} \mathrm{P}\right)\end{array}$} & \multicolumn{2}{|c|}{ 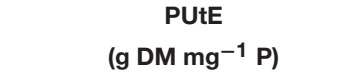 } & \multicolumn{2}{|c|}{$\begin{array}{c}\text { PPUE } \\
\left(g^{2} \text { DM } \mathrm{mg}^{-1} \mathrm{P}\right)\end{array}$} \\
\hline & Low Pi & High Pi & Low Pi & High Pi & Low Pi & High Pi \\
\hline \multicolumn{7}{|l|}{ Coffea arabica } \\
\hline Typica & 213 & 63 & 1.64 & 0.79 & 40.6 & 40.5 \\
\hline Bourbon Vermelho & 221 & 52 & 1.56 & 0.95 & 38.0 & 48.3 \\
\hline Bourbon Amarelo & 299 & 52 & 1.53 & 0.90 & 49.7 & 43.9 \\
\hline Mundo Novo & 245 & 65 & 1.56 & 0.79 & 42.7 & 42.3 \\
\hline Acaiá & 268 & 57 & 1.60 & 0.86 & 49.5 & 43.9 \\
\hline Caturra Vermelho & 306 & 63 & 1.36 & 0.72 & 39.7 & 33.1 \\
\hline Caturra Amarelo & 298 & 60 & 1.44 & 0.69 & 44.0 & 30.3 \\
\hline Catuaí Vermelho & 280 & 56 & 1.46 & 0.75 & 42.3 & 32.8 \\
\hline Catuaí Amarelo & 206 & 60 & 1.54 & 0.73 & 33.6 & 32.7 \\
\hline Icatu Precoce & 299 & 57 & 1.61 & 0.84 & 54.7 & 42.0 \\
\hline Ouro Verde & 300 & 57 & 1.22 & 0.73 & 32.1 & 31.5 \\
\hline Obatã & 255 & 46 & 1.45 & 0.81 & 38.2 & 32.0 \\
\hline Tupi & 268 & 60 & 1.53 & 0.83 & 44.9 & 36.7 \\
\hline E534 Kaffa & 234 & 58 & 1.52 & 0.86 & 39.0 & 44.6 \\
\hline E208 Illubabor & 265 & 47 & 1.48 & 0.96 & 41.1 & 45.8 \\
\hline E22 Sidamo & 252 & 51 & 1.66 & 0.97 & 49.4 & 51.6 \\
\hline E16 Shoa & 270 & 60 & 1.56 & 0.87 & 46.9 & 47.4 \\
\hline E12 Harar & 315 & 56 & 1.54 & 0.88 & 53.8 & 45.9 \\
\hline Jimma Tane & 220 & 49 & 1.45 & 0.83 & 32.9 & 36.5 \\
\hline Geisha & 358 & 48 & 1.59 & 0.95 & 64.9 & 47.4 \\
\hline lemen & 278 & 59 & 1.57 & 0.85 & 49.4 & 44.9 \\
\hline Average $^{a}$ & $269 A b$ & $56 \mathrm{Bb}$ & $1.52 \mathrm{Aa}$ & $0.84 \mathrm{Ba}$ & $44.2 \mathrm{Aa}$ & 40.7Ba \\
\hline \multicolumn{7}{|l|}{ Coffea canephora } \\
\hline Apoatã & 319 & 80 & 1.12 & 0.53 & 28.9 & 24.3 \\
\hline Robusta & 306 & 71 & 1.31 & 0.65 & 37.5 & 29.1 \\
\hline Bukobensis & 317 & 59 & 1.22 & 0.69 & 33.2 & 30.2 \\
\hline Guarini & 254 & 85 & 1.15 & 0.52 & 21.3 & 24.4 \\
\hline Average $^{a}$ & 301Aa & $74 \mathrm{Ba}$ & $1.20 \mathrm{Ab}$ & $0.60 \mathrm{Bb}$ & $30.2 \mathrm{Ab}$ & $27.0 \mathrm{Bb}$ \\
\hline Test F: & \multicolumn{2}{|c|}{$30.66^{*}$} & \multicolumn{2}{|c|}{$45.61^{*}$} & \multicolumn{2}{|c|}{$13.69^{\star}$} \\
\hline Cultivars (C) & \multicolumn{2}{|c|}{$2.08^{*}$} & \multicolumn{2}{|c|}{$12.81^{*}$} & \multicolumn{2}{|c|}{$15.10^{*}$} \\
\hline Treatments (P) & \multicolumn{2}{|c|}{$1504.00^{*}$} & \multicolumn{2}{|c|}{$2065.00^{*}$} & \multicolumn{2}{|c|}{$18.46^{\star}$} \\
\hline Interaction $\mathrm{C} \times \mathrm{P}$ : & \multicolumn{2}{|c|}{$1.95^{\star}$} & \multicolumn{2}{|c|}{$1.40^{\mathrm{ns}}$} & \multicolumn{2}{|c|}{$2.52^{*}$} \\
\hline Least significant difference & 16 & 14 & 0.30 & 0.25 & 15.7 & 14.3 \\
\hline
\end{tabular}

Values followed by the same capital letters do not differ significantly $(P>0.05)$ between treatments and values followed by the same lowercase letters do not differ significantly $(P>$ 0.05) between species.

orthotropic branches, $24 \%$ in leaves, $16 \%$ in fruits, $15 \%$ in roots, and $12 \%$ in plagiotropic branches of plants of C. canephora in production. Correa et al. (1985) found greater $\mathrm{P}$ content in leaves (33\%), followed by fruits (27\%), branches (18\%), stem $(13 \%)$, and roots (9\%). These results are consistent with those observed here. At high $\mathrm{Pi}$, cultivars of $C$. canephora accumulated more $\mathrm{P}$, compared to those of $C$. arabica. This higher $\mathrm{P}$ content in cultivars of $C$. canephora might be associated with the greater root biomass observed in the species.

The PPUE represents the DM production per $\mathrm{P}$ unit present in the same mass portion. In this experiment, the PPUE showed positive correlations with the biometric parameters such as height, diameter, number of leaves, branches, and total DM in plants, all of which are related to plant DM, a significant component in the calculation of PPUE. In turn, the $\mathrm{P}$ concentration correlated negatively with PPUE, i.e., plants that concentrated more $\mathrm{P}$ in tissues showed reduced PPUE. The cultivars with higher PPUE feature lower P content in mature leaves and stem+branches compared to cultivars with lower PPUE (Supplementary Table 4). This lower P concentration in mature leaves and stem + branches could be attributed to $\mathrm{P}$ remobilization from mature tissues and storage organs to 
growing tissues, such as young leaves and roots or a consequence of initial distribution during uptake. This requires further investigation and may provide an interesting trait for breeding new cultivars with improved PPUE.

At low Pi supply, the cultivars Geisha, Icatu Precoce, and E12 Harar had the highest PPUE and Guarani, Apoatã, Bukobensis, and Ouro Verde had the lowest PPUE. This classification is consistent with the classification of Figure 2, which separates all the cultivars by their efficient use of $\mathrm{P}$ and responsiveness to available $\mathrm{Pi}$. In this case, the cultivars with higher PPUE were also classified as efficient and had lower $\mathrm{P}$ concentrations in stems + branches and mature leaves compared to cultivars with lower PPUE. The cultivars Obatã, Ouro Verde, and Bukobensis, classified as inefficient and unresponsive, had lower PUtE and PPUE. Cultivar Obatã still showed low PUpE in high Pi supply, which explains the low responsiveness to added Pi.

In summary, significant variation in PUE and its component traits was observed across a wide genepool of coffee cultivars. Significantly, at the species level, cultivars of C. canephora showed higher PUpE compared to C. arabica and cultivars of $C$. arabica showed higher PUtE compared to C. canephora. Positive correlations between $\mathrm{PUpE}$ and root to shoot ratio were also observed across all cultivars at low Pi supply, suggesting this or root related traits are valuable targets for improving the PUpE of coffee in Pi limited soils. These data provide information about individual cultivars and their suitability for growing under low Pi availabilities and identifies cultivars with contrasting PUE that may be suitable for use in breeding programs to improve these traits in new cultivars. The correlation between roots and PUpE suggests an important role for roots in the acquisition of $\mathrm{Pi}$

\section{REFERENCES}

Amaral, J. F. T., Martinez, H. E. P., Laviola, B. G., Filho, E. I. F., and Cruz, C. D. (2011). Nutrients use efficiency by coffee cultivars. Ciênc. Rural 41, 621-629. doi: 10.1590/S0103-84782011005000027

Bolland, M. D. A., and Gilkes, R. J. (1998). "The chemistry and agronomic effectiveness of phosphate fertilizers," in Nutrient Use in Crop Production, ed Z. Rengel (New York, NY: The Haworth Press), 139-163.

Bragança, S. M., Martinez, H. E. P., Leite, H. G., Santos, L. P., Sediyama, C. S., Victor, H. A. V., et al. (2008). Accumulation of Macronutrients for the Conilon Coffee Tree. J. Plant Nutr. 31, 103-120. doi: 10.1080/01904160701741990

Cordell, D., Drangert, J. O., and White, S. (2009). The story of phosphorus: global food security and food for thought. Global Environ. Chang. 19, 292-305. doi: 10.1016/j.gloenvcha.2008.10.009

Correa, J. B., Garcia, A. W. R., and Costa, P. C. (1985). "Extração de nutrientes pelo cafeeiro Mundo Novo e Catuaí," in Proceedings XII Congresso Brasileiro De Pesquisas Cafeeiras (Caxambú), 35-41.

Fageria, N. K., and Baligar, V. C. (1993). "Screening crop genotypes for mineral stresses," in Proceedings Workshop on Adaptation of Plants to Soil Stresses (Lincoln, NE: Intsormil Publication 94-2), 142-159.

Fawole, I., Gabelman, W. H., Gerloff, G. C., and Nordheim, E. V. (1982). Heritability of efficiency in phosphorus utilization in beans (Phaseolus vulgaris L.) grown under phosphorus stress. J. Am. Soc. Hortic. Sci. 107, 94-97.

Gerloff, G. C. (1977). "Plant efficiencies in the use of N, P and K," in Plant Adaptation to Mineral Stress in Problem Soils, ed M. J. Wright (New York, NY: Cornell University Press), 161-174.

Gunes, A., Inal, A., Alpaslan, M., and Cakmak, I. (2006). Genotypic variation in phosphorus efficiency between wheat cultivars grown under greenhouse by coffee and requires further research to identify specific traits controlling this.

\section{AUTHOR CONTRIBUTIONS}

AN, JF and TT conceived and designed the experiments. AN and TT conducted experiments. AN, JH, TT, and JF contributed to the analysis and interpretation of the data. HC contributed to the statistical analysis of the data. AN, JF, JH, and TT wrote the manuscript; all authors contributed to the discussion and approved the final manuscript.

\section{FUNDING}

We acknowledge funding from São Paulo Research Foundation (FAPESP) Resource for Project Execution Grant number 2010/11744-2 and Scholarship Grant number 2010/11745-9.

\section{ACKNOWLEDGMENTS}

The authors thank Dr. Oliveiro Guerreiro Filho, from Instituto Agronômico de Campinas - IAC for the provision of genetic materials. São Paulo Research Foundation - FAPESP for granting of scholarship and funding for the accomplishment of the project.

\section{SUPPLEMENTARY MATERIAL}

The Supplementary Material for this article can be found online at: http://journal.frontiersin.org/article/10.3389/fpls.2016. 00408 and field conditions. Soil Sci. Plant Nutr. 52, 470-478. doi: 10.1111/j.17470765.2006.00068.x

Hammond, J. P., Broadley, M. R., White, P. J., King, G. J., Bowen, H. C., Hayden, R., et al. (2009). Shoot yield drives phosphorus use efficiency in Brassica oleracea and correlates with root architecture traits. J. Exp. Bot. 60, 1953-1968. doi: 10.1093/jxb/erp083

Lani, J. A., Prezotti, L. C., and Bragança, S. M. (2007). “Cafeeiro," in Manual de Recomendação de Calagem e Adubação para o Estado do Espírito Santo, eds L. C. Prezotti, J. A. Gomes, G. G. Dadalto, and J. A. Oliveira (Vitória: Incaper/SEEA/CEDAGRO), 111-118.

Lynch, J. P. (2007). Roots of the second green revolution. Aust. J. Bot. 55, 493-512. doi: 10.1071/BT06118

Maia, C., DoVale, J. C., Fritsche-Neto, R., Cavatte, P. C., and Miranda, G. V. (2011). The difference between breeding for nutrient use efficiency and for nutrient stress tolerance. Crop Breed. Appl. Biotechnol. 11, 270-275. doi: 10.1590/S198470332011000300010

Manske, G. G. B., Ortiz-Monasterio, J. I., Van Ginkel, M., Gonzalez, R. M., Fischer, R. A., Rajaram, S., et al. (2001). Importance of P uptake efficiency versus P utilization for wheat yield in acid and calcareous soils in Mexico. Eur. J. Agron. 14, 261-274. doi: 10.1016/S1161-0301(00)00099-X

Martins, L. D., Rodrigues, W. N., Machado, L. S., Brinate, S. V. B., Colodetti, T. V., Amaral, J. F. T., et al. (2015). Evidence of genetic tolerance to low availability of phosphorus in the soil among genotypes of Coffea canephora. Genet. Mol. Res. 14, 10576-10587. doi: 10.4238/2015

Mclaughlin, M. J., Fillery, I. R., and Till, A. R. (1991). "Operation of the phosphorus, sulphur and nitrogen cycles," in Australia's Renewable Resources: Sustainability and Global Change, eds R. M. Gifford and M. M. Barson (Canberra: Bureau of Rural Resources), 67-116. 
Oliveira, I. P., Thung, M., Kluthcoushi, J., Aidar, H., and Carvalho, J. R. P. (1987). Avaliação de cultivares de feijão quanto à eficiência no uso do fósforo. Pesqui. Agropec. Bras. 21, 39-45.

Osborne, L. D., and Rengel, Z. (2002a). Screening cereals for genotypic variation in the efficiency of phosphorus uptake and utilisation. Aust. J. Agr. Res. 53, 295-303. doi: 10.1071/AR01080

Osborne, L. D., and Rengel, Z. (2002b). Genotypic differences in wheat for uptake and utilisation of P from iron phosphate. Aust. J. Agr. Res. 53, 837-844. doi: 10.1071/AR01101

Ozturk, L., Eker, S., Torun, B., and Cakmak, I. (2005). Variation in phosphorus efficiency among 73 bread and durum wheat genotypes grown in a phosphorusdeficient calcareous soil. Plant Soil 269, 69-80. doi: 10.1007/s11104-0040469-z

Parentoni, S. N., and Junior, C. L. S. (2008). Phosphorus acquisition and internal utilization efficiency in tropical maize genotypes. Pesqui. Agropec. Bras. 43, 893-901. doi: 10.1590/S0100-204X2008000700014

Reis, R. A. Jr., and Martinez, H. E. P. (2002). Adição de Zn e absorção, translocação e utilização de Zn e P por cultivares de cafeeiro. Sci. Agric. 59, 537-542. doi: 10.1590/S0103-90162002000300019

Rose, T. J., and Wissuwa, M. (2012). Rethinking internal phosphorus utilization efficiency (PUE): a new approach is needed to improve PUE in grain crops. Adv. Agron. 116, 185-217. doi: 10.1016/B978-0-12-394277-7. 00005-1

Shenoy, V. V., and Kalagudi, G. M. (2005). Enhancing plant phosphorus use efficiency for sustainable cropping. Biotechnol. Adv. 23, 501-513. doi: 10.1016/j.biotechadv.2005.01.004

Sousa, D. M. G., and Lobato, E. (2003). Adubação Fosfatada em Solos da Região do Cerrado. Piracicaba: Potafos Informações Agronômicas.

Tezotto, T., Favarin, J. L., Neto, A. P., Gratão, P. L., Azevedo, R. A., and Mazzafera, P. (2013). Simple procedure for nutrient analysis of coffee plant with energy dispersive X-ray fluorescence spectrometry (EDXRF). Scientia Agricola 70, 219-297. doi: 10.1590/S0103-90162013000400007

Tomaz, M. A., Martinez, H. E. P., Cruz, C. D., Ferrari, R. B., Zambolim, L., and Sakiyama, N. S. (2008). Genetics differences in the efficiency of absorption, translocation and use of $\mathrm{K}, \mathrm{Ca}$ and $\mathrm{Mg}$ in grafted seedlings of coffee. Ciênc. Rural 38, 1540-1546. doi: 10.1590/S0103-847820080006 00008

Tomaz, M. A., Martinez, H. E. P., Rodrigues, W. N., Ferrari, R. B., Pereira, A. A., and Sakiyama, N. S. (2011). Efficiency of absorption and utilization of boron, zinc, copper and manganese in grafted coffee seedlings. Rev. Ceres 58, 108-114. doi: 10.1590/S0034-737X2011000100016

Tomaz, M. A., Silva, S. R., Sakiyama, N. S., and Martinez, H. E. P. (2003). Efficiency of uptake, translocation and use of calcium, magnesium and sulphur in young Coffea arabica plants under the influence of the rootstock. Rev. Bras. Ciênc. Solo 27, 885-892. doi: 10.1590/S0100-06832003000500013
USGS (2012). "United state geological survey," in Mineral Commodity Summaries (U.S. Geological Survey), 198. Available online at: http://minerals.er.usgs.gov/minerals/pubs/mcs/2012/mcs2012.pdf (Accessed on 21 May 2012).

Van Raij, B., Quaggio, J. A., and da Silva, N.M. (1986). Extraction of phosphorus, potassium, calcium, and magnesium from soils by an ionexchange resin procedure. Commun. Soil Sci. Plant Anal. 17, 547-566. doi: 10.1080/00103628609367733

Vance, C. P., Uhde-Stone, C., and Allan, D. L. (2003). Phosphorus acquisition and use: critical adaptations by plants for securing a non-renewable resource. New Phytol. 157, 423-447. doi: 10.1046/j.1469-8137.2003.00695.x

Voltan, R. B. Q., Fahl, J. I., and Carelli, M. L. C. (1992). Variação na anatomia foliar de cafeeiros submetidos a diferentes intensidades luminosas. Rev. Bras. Fisiol. Veg. 4, 99-105.

Vose, P. B. (1987). "Genetical aspects of mineral nutrition progress to date," in Genetic Aspects of Plant Mineral Nutrition, eds H. W. Gabelman and B. C. Louhman (Dordrecht: Boston and Lancaster), 3-13.

Wang, X., Shen, J., Liao, H. (2010). Acquisition or utilization, which is more critical for enhancing phosphorus efficiency in modern crops? Plant Sci. 179, 302-306. doi: 10.1016/j.plantsci.2010.06.007

White, P. J., Broadley, M. R., Greenwood, D. J., and Hammond, J. P. (2005). "Genetic modifications to improve phosphorus acquisition by roots," in Proceedings 568 (York: International Fertiliser Society).

Wiel, C. C. M., Linden, C. G., and Scholten, O. E. (2016). Improving phosphorus use efficiency in Agriculture: opportunities for breeding. Euphytica 207, 1-22. doi: 10.1007/s10681-015-1572-3

Wissuwa, M., and Ae, N. (2001). Genotypic variation for tolerance to phosphorus deficiency in rice and the potential for its exploitation in rice improvement. Plant Breed. 120, 43-48. Doi: 10.1046/j.1439-0523.2001.00561.x

Conflict of Interest Statement: The authors declare that the research was conducted in the absence of any commercial or financial relationships that could be construed as a potential conflict of interest.

The reviewer $\mathrm{BD}$ and handling Editor $\mathrm{RB}$ declared their shared affiliation, and the handling Editor states that the process nevertheless met the standards of a fair and objective review.

Copyright (C) 2016 Neto, Favarin, Hammond, Tezotto and Couto. This is an openaccess article distributed under the terms of the Creative Commons Attribution License (CC BY). The use, distribution or reproduction in other forums is permitted, provided the original author(s) or licensor are credited and that the original publication in this journal is cited, in accordance with accepted academic practice. No use, distribution or reproduction is permitted which does not comply with these terms. 